\title{
Experimental studies of thin films deposition by magnetron sputtering method for CIGS solar cell fabrication
}

\author{
Stawomir Gułkowski ${ }^{1}$, and Ewelina Krawczak ${ }^{1, *}$ \\ ${ }^{1}$ Faculty of Environmental Engineering, Lublin University of Technology, Nadbystrzycka 38, 20-618 Lublin, Poland
}

\begin{abstract}
Among a variety of the thin film solar cell technologies of second generation, copperindium-gallium-diselenide device (CIGS) with the latest highest lab cell efficiency record of $22.4 \%$ seems to be the most promising for the power generation. This is partly due to the advantages of using low cost films of few microns thick not only as a metallic contacts but also as a main structure of the solar cell consisted of high quality semiconductor layers. This paper reports the experimental studies of the CIGS absorber formation on Soda Lime Glass substrate covered by thin molybdenum film as a back contact layer. All structures were deposited with the use of magnetron sputtering method only. Technological parameters of the deposition process such as deposition power, pressure and deposition time were optimized for each layer of the structure. Mo back contact was examined in terms of resistivity. EDS measurements were carried out to verify stoichiometric composition of CIGS absorber. Thin film of $\mathrm{Al}$ was used as a top contact in order to examine the quality of $p-n$ junction. The I-V electrical characteristic of the $p$ - $n$ junction was analysed in terms of solar cell application.
\end{abstract}

\section{Introduction}

$\mathrm{CuInGaSe}_{2}$ solar cells based on copper-indium-galliumdiselenide (CIGS) absorber become one of the promising devices in the photovoltaic industry mainly due to attractive properties of this $p$-type material such as direct band gap, high absorption coefficient and inherent $p$-type conductivity $[1,2]$. CuInGaSe 2 absorber was also found to be high tolerant material to variations in compositions $[3,4]$. What is more, the recent highest noticed efficiencies of the lab solar cells equals $22.4 \%$ are close to the efficiencies of the silicon devices, which makes possible to replacing $\mathrm{Si}$ crystalline solar cells with the CIGS [5]. For a large scale CIGS module the efficiency of $15 \%$ is comparable to crystalline silicon devices as well [6]. More than $80 \%$ of the current solar cells production requires cutting of large silicon crystal. The technology which could avoid the material losses can be a method for future developing cost-efficient solar cells $[7,8]$. Basic device structure of these two technologies is the same. Crystalline silicon solar cells are built on the basis of $p-n$ junction of silicon material with different types of doping. CIGS solar cells based on the $p-n$ junction of $\mathrm{CuInGaSe}_{2} / \mathrm{CdS}$ structure. CIGS/CdS junction is deposited on soda lime glass substrate (SLG), covered by Mo layer of one micron thick [1]. Because of its high conductivity and relative stability at the high processing temperature molybdenum was found to be the best back contact material for CIGS solar cells. Mo layer is usually deposited using DC magnetron sputtering technique. Properties of the grown films play a crucial role in the performance of the CIGS device [9]. For this reason, parameters of the deposition process such as power, time and pressure should be carefully chosen. In terms of CIGS absorber, several deposition methods have been reported. Nowadays, the highest efficiency devices are produced using co-evaporation technique $[1,10]$. In the process the $\mathrm{Cu}, \mathrm{In}, \mathrm{Ga}$ and $\mathrm{Se}$ are delivered from open-boat sources under different temperature to the heated substrate. The main advantage of this method is flexibility to choose the process specific and control the film composition and bandgap [1]. However, the main disadvantage of this technique is to obtain the uniform deposition over large areas [11]. Another method of CIGS structure preparation is sputtering of metallic precursor consisted of $\mathrm{Cu}$, In and $\mathrm{Ga}$ with required stoichiometric ratios of $\mathrm{Cu} /(\mathrm{In}+\mathrm{Ga})$ and $\mathrm{Ga} /(\mathrm{In}+\mathrm{Ga})[12,13]$. In order to crystallize the absorber, the post-selenization process is followed by heating precursor layers at temperature up to $600^{\circ} \mathrm{C}$ under the Se atmosphere $[14,15]$. Promising alternative method is the sputtering deposition of CIGS absorber directly from the single quaternary target consisted of metals as well as Se under the high temperature without additional postselenization step $[11,16,17]$. In order to form a $p-n$ junction, CdS film has to be deposited on the CIGS absorber. The highest performance of CIGS solar cells were achieved with the use of chemical bath deposition (CBD) of the CdS layer [18,19]. The CBD process is simple and very attractive for devices of small, laboratory size cells. However, in commercial application CBD method is slow and produces liquid

*Corresponding author: e.krawczak@pollub.pl 
wastes that need to be recycled. For this reason, interest of other deposition techniques as magnetron sputtering has grown over the last few years [20,21]. Formed $p-n$ junction must have top conductivity contact. The obvious choice is transparent oxide. The main materials that can be used are as follows: $\mathrm{SnO}_{2}, \mathrm{In}_{2} \mathrm{O}_{3}: \mathrm{Sn}$ (ITO) or $\mathrm{ZnO}$. The most common is $\mathrm{ZnO}$ due to low material costs. The transparent conductive oxide can be deposited by RF magnetron sputtering from ceramic target [1]. Aluminum contact grid completes the device.

In this work fabrication of $\mathrm{CuInGaSe}_{2} / \mathrm{CdS}$ junction on the Mo covered SLG substrate was shown. Aluminum and molybdenum contacts as well as $p$-type absorber and $n$-type CdS layer were deposited using DC/RF magnetron sputtering method. Single quaternary $\mathrm{CuInGaSe}_{2}$ target was used for absorber deposition under temperature of $400^{\circ} \mathrm{C}$. Technological parameters of the film deposition process were carefully chosen to achieve the thickness of the particular layer as well as to control the stoichiometric concentration of the absorber. $\mathrm{I}-\mathrm{V}$ dark curve of the SLG/Mo/CIGS/CdS/Al structure was measured in order to examine the quality of the $p-n$ junction.

\section{Materials and methods}

Thin films of the CIGS structure were formed using only sputtering system, RF or DC in dependence of conductive or nonconductive material of the target. Size of the target was 4" in diameter and $6 \mathrm{~mm}$ thick. The structure was formed on soda lime glass (SLG) substrate of $1 \mathrm{~cm} \mathrm{x} 1 \mathrm{~cm}$ size. Prior to deposition process the glass substrates were chemically cleaned in acetone, distilled water and ethanol for 10 min respectively, and dried in a $\mathrm{N}_{2}$ gas. The vacuum chamber was evacuated to a background pressure of $1.0 \times 10^{-2} \mathrm{~Pa}$. Argon working gas of high purity (99.99\%) was introduced into deposition chamber in presputtering and sputtering process. In order to find the deposition rates of particular materials, several experiments were carried out at constant deposition power of $80 \mathrm{~W}\left(1 \mathrm{~W} / \mathrm{cm}^{2}\right)$ and pressure of about $2 \mathrm{~Pa}$ for different deposition times. Precise thickness measurements were carried out using Bruker DektakXT profiler. The four point probe RM 3000+ system of Jandel Engineering was used to find the best conductivity of the back and top contact film. Both $\mathrm{CuInGaSe}_{2}$ and $\mathrm{CdS}$ structures were examined in terms of deposition rate as well as film composition using energy dispersive spectroscopy (EDS) of Hitachi SU3500 Scanning Electron Microscopy. Table 1 presents optimal set of parameters that was chosen for each material to form final device.

Table 1. Technological parameters of the magnetron sputtering process of particular films deposition.

\begin{tabular}{|c|c|c|c|}
\hline & $\begin{array}{c}\text { Power } \\
{[\mathrm{W}]}\end{array}$ & $\begin{array}{c}\text { Pressure } \\
{[\mathrm{Pa}]}\end{array}$ & $\begin{array}{c}\text { Deposition time } \\
{[\mathrm{min}]}\end{array}$ \\
\hline Molybdenum & 80 & $1.99 \mathrm{~Pa}$ & 45 \\
\hline CIGS & 80 & $1.99 \mathrm{~Pa}$ & 90 \\
\hline CdS & 80 & $2.09 \mathrm{~Pa}$ & $1 \mathrm{~min} 22 \mathrm{sec}$ \\
\hline
\end{tabular}

I-V dark characteristic of the obtained structure was measured in a solar cell simulator.

\section{Results and discussion}

Fig. 1 shows the thickness measurements results of the molybdenum thin films as a function of the deposition time. The technological parameters such as deposition power and pressure were kept constant equals $80 \mathrm{~W}$ and $1.98 \mathrm{~Pa}$ respectively.

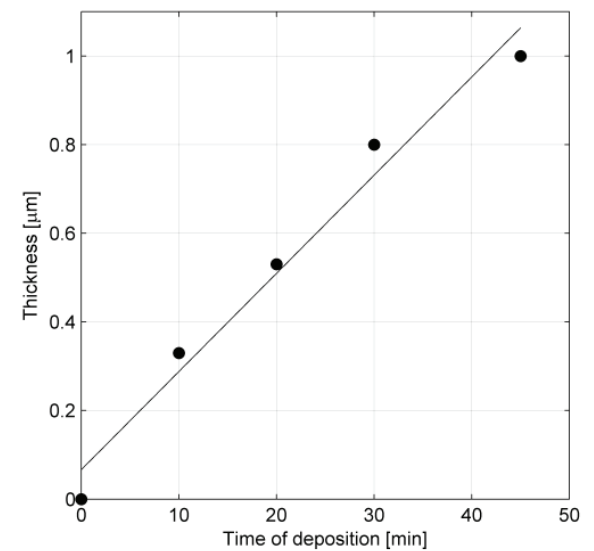

Fig 1. Thickness of the Mo layer as a function of deposition time at constant deposition power of $80 \mathrm{~W}$ and pressure about $2 \mathrm{~Pa}$.

From the figure, linear correlation between deposition time and film thickness can be observed. On the basis of linear regression analysis Mo deposition rate was estimated to be $0.38 \mathrm{~nm} / \mathrm{s}$.

The four point probe resistivity measurements were carried out in order to examine the conductivity of the Mo thin film. Results of the examination were shown in Fig. 2.

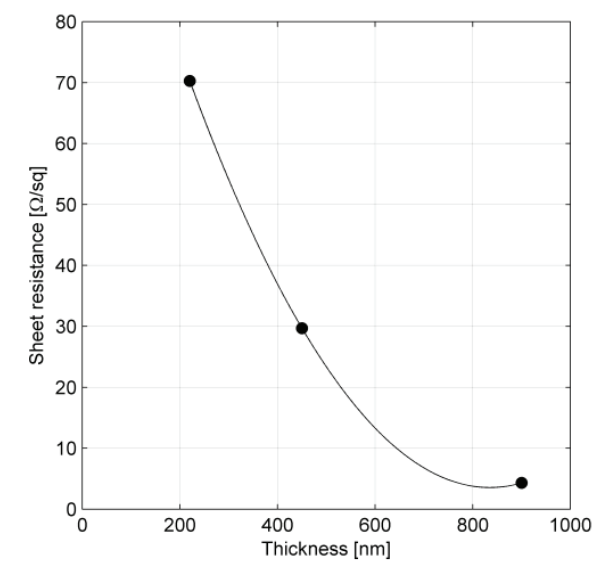

Fig. 2. Sheet resistance dependence on the layer thickness at constant deposition power of $80 \mathrm{~W}$.

Fig. 2 depicts that sheet resistance of the films decreases with the increase of its thickness. One micron thick Mo layer prepared at deposition power of $80 \mathrm{~W}$ was characterized by sheet resistance equal to about $4 \Omega / \mathrm{sq}$. The resistivity of the film was found to be $2 \mathrm{~m} \Omega \cdot \mathrm{cm}$. 
This value is within the range of resistivity values for various deposition power reported by [8].

Fig. 3 shows the dependence of CIGS layer thickness on deposition time at constant deposition power of $80 \mathrm{~W}$ and pressure of $1.99 \mathrm{~Pa}$.

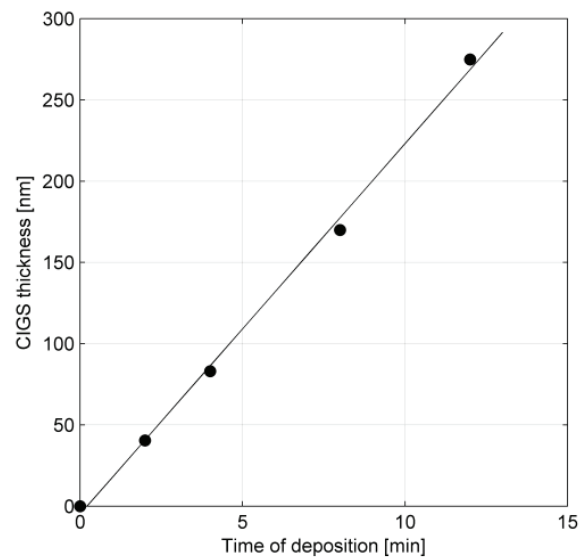

Fig. 3. CuInGaSe 2 film thickness versus deposition time at constant power of $80 \mathrm{~W}$. Temperature of glass substrate was equal to $400^{\circ} \mathrm{C}$ during the deposition process.

The temperature of the glass substrate was kept constant at $400^{\circ} \mathrm{C}$ throughout the deposition process. From the results of linear regression applied to the data the deposition rate of CIGS film was determined. Deposition time of at least 2 microns layer was found to be about 90 min. SEM image of the top surface of the CIGS film deposited at parameters described above was shown in Fig. 4.

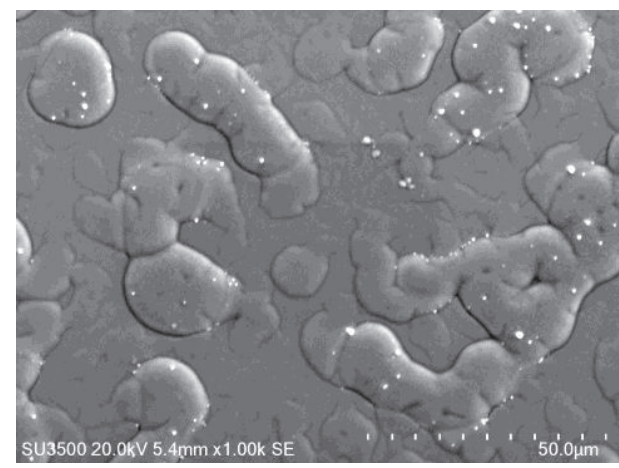

Fig. 4. SEM image of the top surface of two microns CIGS thin film deposited at power of $80 \mathrm{~W}$ and substrate temperature of $400^{\circ} \mathrm{C}$.

In order to obtain the chemical composition of CIGS absorber, energy dispersive spectroscopy measurements (EDS) were carried out. Sample was observed under $10 \mathrm{kV}$ mode. Fig. 5 shows EDS profile of the sample. Atomic composition of the film was as follows: $\mathrm{Cu}$ 14.8 at $\%$, In -18.35 at $\%, \mathrm{Ga}-2.86$ at $\%, \mathrm{Se}-$ 25.95 at $\%$. On the basis of measured values the relative ratios of $\mathrm{Cu} /(\mathrm{In}+\mathrm{Ga})$ and $\mathrm{Ga} /(\mathrm{In}+\mathrm{Ga})$ were found to be 0.7 and 0.13 respectively. Calculated values are within the ranges of CIGS absorber composition ratios [12]. In order to examine the quality of the $p-n$ junction the high conductivity $\mathrm{Al}$ contact was deposited on the top of the structure and dark electrical I-V characteristic was measured.

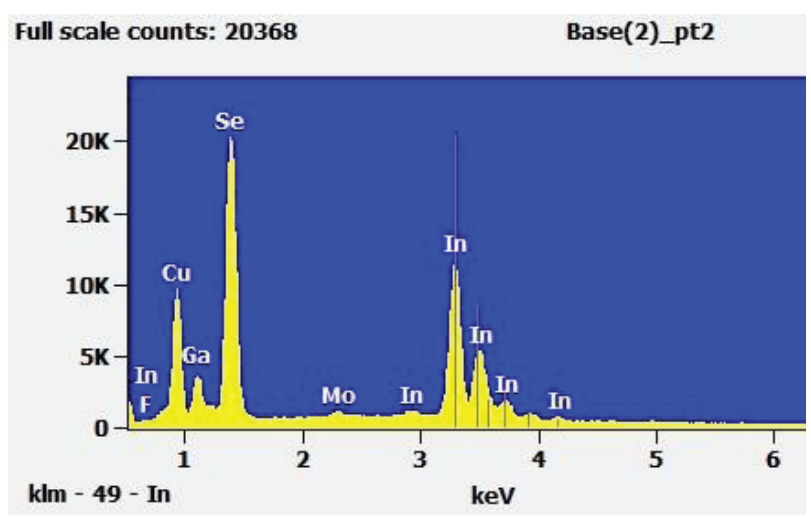

Fig. 5. EDS spectral analysis of the top surface of CIGS absorber.

Similar to previously described procedure of deposition rate determination measurements of thickness versus deposition time were carried out for $\mathrm{CdS}$ material. From the line of best fit the deposition rate was found to be $0.77 \mathrm{~nm} / \mathrm{s}$. CdS film of $60 \mathrm{~nm}$ thick needs about $78 \mathrm{~s}$ of the deposition at power of $80 \mathrm{~W}$ and pressure of $2.09 \mathrm{~Pa}$.

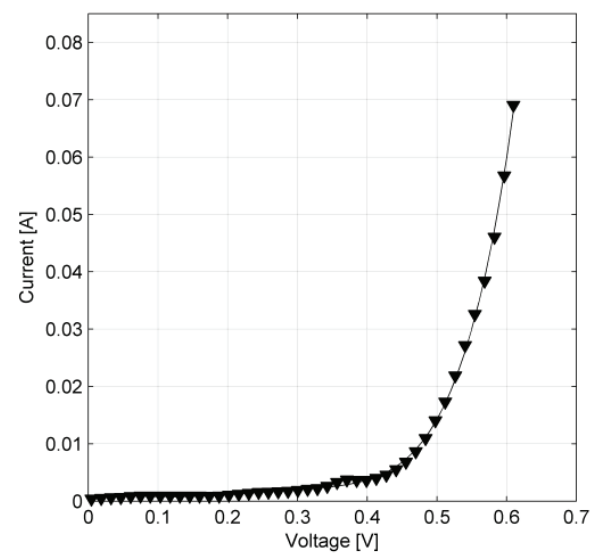

Fig. 6. Experimental dark I-V characteristics of $\mathrm{CuInGaSe}_{2} / \mathrm{CdS}$ junction.

The exponential shape of the I-V curve (Fig. 6) was found to be typical characteristic of the high quality diode. The presence of $p-n$ junction of the $\mathrm{CuInGaSe}_{2} / \mathrm{CdS}$ structure inside the device was proved. Further analysis of the device demands a transparent conductive oxide deposition on the top of the structure to have transparent contacts that allow the light curve measurements and the main parameters of the solar cell extraction [22].

\section{Conclusions}

CIGS solar cells become a promising alternative solution for common Si-crystalline devices in terms of high efficiency as well as low production costs. However, $\mathrm{CuInGaSe}_{2} p$-type absorber, the main part of the structure needs to be improved in a large scale production. Magnetron sputtering deposition seems to be 
a good solution for this purpose because allows to obtain a complete solar device in one technological process. This study reported the process of CIGS device formation from Mo back contact to aluminum top contact with the use of sputtering deposition technique. Technological parameters of sputtering process such as deposition power, pressure and time were found to be optimal. Deposition rates of particular materials were established to obtain demanded thickness of each layer. Mo contact layers were examined in terms of resistivity. Sheet resistance of one micron Mo layer was found to be about $4 \Omega /$ sq. EDS measurements were carried out to verify stoichiometric composition of the CIGS absorber. Relative ratios of $\mathrm{Cu} /(\mathrm{In}+\mathrm{Ga})$ and $\mathrm{Ga} /(\mathrm{In}+\mathrm{Ga})$ were found to be 0.7 and 0.13 respectively. I-V dark characteristic was measured. The shape of the curved was found to be typical diode exponential shape which proved the high quality $p-n$ junction presence inside the structure.

Authors would like to thank Alain Fave from Institut National des Sciences Appliquées de Lyon for possibility to measure film profiles.

\section{References}

1. S. Hegedus and A. Luque, in Handbook of Photovoltaic Science and Engineering, 2nd ed., edited by A. Luque and S. Hegedus, (John Wiley \& Sons, Chichester, 2011)

2. C. Men, Z. Tian, Q. Shao, H. Zhang, Z. An, Appl. Surf. Sci. 258 (2012)

3. R. Rocheleau, J. Meakin, R. Birkmire, Proc. 19th IEEE Photovoltaic Specialist Conf. (1987)

4. K. Mitchell, C. Eberspacher, J.H. Ermer, K. L. Pauls, D. N. Pier. IEEE Trans. Electron Devices 37, 2 (1990)

5. P. Jackson, R. Wuerz. D. Hariskos, E. Lotter, W. Witte, M. Powalla, Phys. Status Solidi RRL 10 (2016)

6. K.A.W. Horowitz, R. Fu, M. Woodhouse, Sol. Energ. Mat. Sol. C 154 (2016)

7. S. Gulkowski, J.M. Olchowik. Annu. Set Environ. Prot. 15 (2013)

8. J.M. Olchowik, S. Gulkowski, K. Cieslak, I. Jozwik, A. Fave, A. Kaminski, J. Non-Cryst. Solids 354 (2008)

9. S. A. Pethe, E. Takahashi, A. Kaul, N. G. Dhere, Sol. Energ. Mat. Sol. C 100 (2012)

10. P. Jackson, D. Hariskos, E. Lotter E, S. Paetel, R. Wuerz, R. Menner, W. Wischmann, M. Powalla, Prog. Photovolt. Res. Appl. 19 (2011)

11. J.A. Frantz, R.Y. Bekele, V.Q. Nguyen, J.S. Sanghera, A. Bruce, S.V. Frolov, M. Cyrus, I.D. Aggarwal, Thin Solid Films 519 (2011)

12. S. Gulkowski, E. Krawczak, J.M. Olchowik. Proc. of the $31^{\text {st }}$ EU PVSEC Conf. (2015)

13. S. Gulkowski, J. Civ. Eng. Environ. Archit., JCEEA, XXXIII 63 (2016)
14. C.Y. Hsu, P.C. Huang, Y.Y. Chen, D.C. Wen. Int. J. Photoenergy, 2013 (2013)

15. M. Acciarri, S. Binetti, A. Le Donne, B. Vodopivec, L. Miglio, S. Marchionna, M. Meschia, R. Moneta. Proc. of the $27^{\text {th }}$ EU PVSEC Conf. (2012)

16. H. Kong, J. He, L. Huang, L. Zhu, L. Sun, P. Yang, J. Chu, Mater. Lett. 116 (2014)

17. G.-X. Liang, P. Fan, C. - M. Chen, Z.-H. Zheng, D.P. Zhang, J. Alloy Compd. 610 (2014)

18. P. Lisco, P.M. Kaminski, A. Abbas, K. Bass, J.W. Bowers, G. Claudio, M. Losurdo, J. M. Walls, Thin Solid Films 582 (2015)

19. S. Lee, Eun Soo Lee, Tae Yeon Kim, Jun Sik Cho, Young Joo Eo, Jae Ho Yun, Ara Cho, Sol. Energy Mater. Sol. Cells 141 (2015)

20. A. Punoose, M. Marafi, G. Prabu, F. El Akkad, Phys. Stat. Sol. A 177 (2000)

21. D. Kim, Y. Park, M.Kim, Y. Choi, Y.S. Park, J. Lee. Mater. Res. Bull. 69 (2015)

22. A. Zdyb, E. Krawczak, P. Lichograj, Opt. Appl. 46 (2016) 